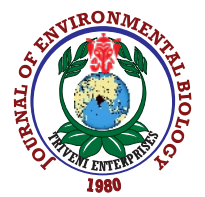

\title{
Determination of antifungal efficiency of some fungicides and secondary metabolites of Trichoderma species against Botrytis cinerea
}

\author{
N.G. Savas ${ }^{1 *}$, M. Yıldız ${ }^{1}$, R. Eltem ${ }^{2}$ and E. Ozkale ${ }^{3}$ \\ ${ }^{1}$ Plant Health Department, Viticulture Research Institute, Ministry of Agriculture and Forestry, Number: 168, 45125, Manisa/Turkey \\ ${ }^{2}$ Department of Bioengineering, Faculty of Engineering, Ege University, Number:180, 35040, İzmir/ Turkey \\ ${ }^{3}$ Department of Biology, Faculty of Arts and Sciences, Manisa Celal Bayar University, 45140, Manisa/Turkey \\ *Corresponding Author Email : nurdangungor79@hotmail.com
}

Received: 06.07.2020

Revised: 17.11 .2020

Accepted: 05.03.2021

\section{Abstract}

Aim: The present study aimed to investigate the antifungal effects of fenhexamid, cyprodinil+fludioxanil, Bacillus subtilis QST 713, Trichoderma secondary metabolites (EGE-K-38 and EGE-K-71) on 6 isolates of necrotrophic fungi (Botrytis cinerea) under in- vitro conditions.

\begin{abstract}
Methodology: A dual culture technique was used to evaluate the effects of volatile compounds produced by Trichoderma in culture media against Botrytis cinerea isolates. For non-volatile and volatile metabolites, measurements for growth inhibition were made with the mixture of filter sterilized liquid medium of Trichoderma and potato dextrose agar. The fungicidal effects of these non-volatile metabolites and fungicides were first evaluated according to the effective concentration $\left(E_{50}\right)$ data of growing mycelium inhibition of disease agents.
\end{abstract}

Results: According to the results obtained, the drug/agent with the lowest fungicidal activity was determined as fenhexamide, which seems to have the lowest $\mathrm{EC}_{50}$ value of $0.05 \mathrm{ug} \mathrm{m} \mathrm{l}^{-1}$. Both non-volatile metabolites and volatile metabolites of Trichoderma strains showed strong inhibition against $B$. cinerea isolates under experimental conditions. The highest growth inhibition percentage was determined with volatile metabolites of Trihoderma atroviride EGE-K-71 strain as $71.8 \%$.

Interpretation: The study suggest that filtrates that contain secondary metabolites and volatile compounds of Trichoderma strains produced in both liquid culture and dual culture conditions can be used as an effective fungal control agents against pre and postharvest contamination of grapes with Botrytis cinerea.

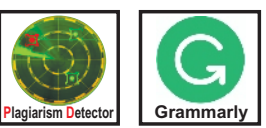

Key words: Botrytis cinerea, Fungicides, Non-volatile compounds, Trichoderma

How to cite : Savas, N.G., M. Yıldı, R. Eltem and E. Ozkale: Determination of antifungal efficiency of some fungicides and secondary metabolites of Trichoderma species against Botrytis cinerea. J. Environ. Biol., 42, 705-713 (2021). 


\section{Introduction}

The production of grapes in Turkey was 4.1 million metric tons in 2018 which constitutes $6.8 \%$ of the total world production and, is one of most important export fruit products of Turkey. Turkey is the world's largest raisin producer with 1.2 million metric tons of raisin production (FAO, 2018). Turkey exports $85 \%$ of the raisin to European Union countries (Akgül et al., 2015). Botrytis cinerea Pers ex Fr is a major global pathogen that causes gray mold disease (also known as Botrytis bunch rot) and results in severe loss in more than 200 host species (Elmer and Michailides, 2007). B. cinerea is responsible for pre- and postharvest losses in grapevines also. The estimated loss caused by $B$. cinerea in vineyards is reported to be about $\$ 2$ billion per year (Elad et al., 2007). Botrytis cinerea is difficult to control due to its different attacking modes, survival under less favourable conditions for extended periods as sclerotia in crop debris and development of fungicide-resistant strains (Williamson etal., 2007).

Chemical control of noble mold caused by Botrytis cinerea has always been very important, however, continuous use of same fungicide against the same pathogen causes the development of fungicide-resistant strains (Kumar and Dubey, 2001; Mamgain et al., 2013). In addition, chemical fungicides not only leads to the development of fungicide-resistant species but also accumulates as residues in food and groundwater. Due to the environmental hazards and harmful side effects on humans and animals, $B$. cinerea is well known as being a "high risk" fungus that quickly develops resistance (Amiri et al., 2014). In many studies, it has been reported that $B$. cinerea isolates have developed resistance against many fungicide groups such as benzimidazole, dicarboximide, phenylpyrroles, anilinopyrimidine, hydroxyanilides and SDHI (Mamiev et al., 2013; Leroux et al., 2002; Leroux, 2004). Studies conducted in the Aegean and Marmara regions of Turkey, resistance against gray mold isolates on grapes have also been reported (Koplay et al., 2004). Different reports on the development of fungicide resistant strains of pathogens have also been reported earlier (Kumar and Dubey, 2001; Mamgain et al., 2013).

A recent worldwide trend on disease/plant control management is the use of environmentally friendly methods such as biological control (Hajieghrari et al., 2010). Biological control includes the use of antagonistic microorganisms that occur naturally in soil (Karkachi et al., 2010; Abano and Sam-Amoah, 2012). Alternative methods have been developed to protect vineyards against the negative effects of fungicides and to counter resistance. Biological control plays an important role in the fight against $B$. cinerea. Along with the scope of the European Union (EU) integration process, biological control has gained importance by allowing at least five active substances in the range of maximum residue limit (MRL) values in grapes exported in recent years (Yanar et al., 2015). Trichoderma is a genus of fungi containing anamorphic fungi that have been isolated mainly from soil and decay organic matter (Harman et al., 2004). Trichoderma species have antagonistic effects against various soil phytopathogens, including fungi such as Fusarium oxysporum, Rhizoctonia solani, Sclerotium rolfsii, and Verticillium dahliae (Spiegel and Chet, 1998; Jabnoun-Khiareddine, et al., 2009). The antagonistic activity shown by Trichoderma species has been linked to mycoparasitism, competition for nutrients and niche, production of antibiotics, and enzymes (Verma et al., 2007). The antagonism of Trichoderma spp. was observed in both in-vitro conditions (Mishra et al., 2011) as well as in greenhouse and field trials (Kexiang et al., 2002). Some species of Trichoderma also promote plant growth and improve nutrient uptake, resulting in better production of plant hormones and vitamins (Joshi et al., 2010). Trichoderma species are efficient in terms of hyperparasitism and nutritional competition in addition to their abilities to produce antibiotics, and they can be used as good antagonists against both soil pathogens and pathogens that can infect leaves and fruits (Gezgin et al., 2019).

It has been determined that $T$. harzianum is capable of controlling pathogens $B$. cinerea, Altrenaria alternata and Fusarium acuminatum in in-vitro studies (Mokhtar and Aid, 2013). Trichodex (T. harzianum) is used against diseases of $B$. cinerea, Sclerotinia sclerotiorum, Cladosporium fulvum in greenhousegrown tomatoes and cucumbers and vineyards (Freeman et al., 2004). Binab T (T. harzianum and T. polysporum) controls wound rot and trunk diseases (Mehrotra and Aggarwal, 2003), and might stimulate Supresivit (T. harzianum) Phytophthora spp. and Pythium ultimum and the growth of plants (Brožová, 2004). There are limited studies on Trichoderma spp., which causes cluster rotting in vineyards, or on the biological control of post-harvest pathogen $B$. cinerea. The objective of the present study was to investigate the antifungal effects of fenhexamid, cyprodinil +fludioxanil, Bacillus subtilis QST 713, Trichoderma secondary metabolites (EGE-K-38 and EGE-K-71) on six isolates of necrotrophic fungus (Botrytis cinerea) obtained from grapes in the aegean region of Turkey under in-vitro and control conditions.

\section{Materials and Methods}

Fungal species: Trichoderma harzianum EGE-K-38 and Trichoderma atroviride EGE-K-71 isolates identified as morphological and molecular were obtained from the Department of Bioengineering, Faculty of Engineering, Ege University. Morphological traits of Trichoderma spp. were evaluated according to Hoyos- Carvajal et al. (2009). Their genomic DNAs were isolated by the EurX geneMatrix DNA Isolation Kit according to the manufacturer's instructions. Amplification conditions for rRNA regions of nuclear internally transcribed spacers (ITS 1 \& 2 ) and tef 1 gene primers were used (Hoyos-Carvajal et al., 2009). Amplicons were purified and sequenced by TrioGene firm. For species identification, sequences were subjected to analysis by BlastN National Center for Biotechnology Information (NCBI).

B. cinerea isolates were collected from diseased clusters in different commercial vineyards in the Aegean region in 20182019. Conidiophore and spore masses were transferred directly to the PDA (potato dextrose agar, Oxoid) media and incubated at 
$22 \pm 2^{\circ} \mathrm{C}$ for $5-7$ days. Six of them were selected and kept for later use in Eppendorf tubes containing water with $20 \%$ glycerol at $20^{\circ} \mathrm{C}$ in the Plant Health Laboratory Fungal Culture Collection of the Manisa Viticultural Research Institute.

Fungicides: Three commercial fungicides were used in this study to compare antifungal activity: Teldor@ SC 500 (fenhexamid $500 \mathrm{gl}^{-1}$, Bayer), Switch $62.5 \mathrm{WG}$ (cyprodinil 37.5\% + fludioxonil $25 \%$, Syngenta) and Serenade $®$ SC (1.34\% Bacillus subtilis QST 713 strain, min. $1.0 \times 10^{9} \mathrm{cfu}^{\mathrm{ml}} \mathrm{l}^{-1}$, Bayer).

Dual culture technique: The dual culture technique, defined by Morton and Stroube (1955), was used to test the antagonistic efficiencies of volatile metabolites (VM) of $T$. harzianum and $T$. atroviride against $B$. cinerea isolates. $B$. cinerea and Trichoderma strains were grown at room temperature $\left(25^{\circ} \mathrm{C}\right)$ in PDA for a week. Agar discs with diameters of $5 \mathrm{~mm}$ were cut from around the developing colony of $B$. cinerea isolates and were later transferred to the petri dishes containing PDA. After the 2-day development of the isolates, the 5-mm agar discs of Trichoderma species were cultured on the opposite end of the isolates in the petri dish and incubated at room temperature with a light-dark regimen of 8-12 hr, and were observed periodically. The experiment was replicated four times according to the design of the randomized plot, and incubated at $28^{\circ} \mathrm{C}$. Radial growth of the antagonists and pathogen was measured at 24-hr intervals until day 7 , and the percentage of inhibition over control for each treatment was calculated according to Hajieghrari (2010).

Non-volatile metabolites: To obtain the liquid phase (filtrate) of non-volatile metabolites (non-VM), all Trichoderma test strain were cultured with $100 \mathrm{ml}$ sterilized potato dextrose broth medium (PDB) in $250 \mathrm{ml}$ Erlenmeyer flasks over an orbital shaker at 150 rpm at $26^{\circ} \mathrm{C}$ for 25 days. Later, the liquid phase was collected by filtering through sterile filter paper (or gauze) and centrifuged to remove fungal spores. The liquid phase was filtered through cellulose membranes with a diameter of $0.2 \mu$ m and was prepared for use in fungicidal susceptibility tests at a concentration of $25 \%$ (v/v) and included in PDA medium $\left(45^{\circ} \mathrm{C}\right.$ ) (Marques et al., 2018). The experiment was carried out with three replications according to the design of the randomized plot.

Determination of antifungal efficiency against $B$. cinerea isolates of fungicides and non-volatile metabolites in-vitro: In fungicidal efficiency tests, the commercial fungicide formulations of cyprodinil + fludioxonil, fenhexamide, $1.34 \%$ Bacillus subtilis QST 713 strain (min. $1.0 \times 10^{9} \mathrm{cfu}^{\mathrm{m} l^{-1}}$ ) and nonvolatile filtrates of $T$. harzianum and $T$. atroviride of $25 \%\left(\mathrm{v} . \mathrm{v}^{-1}\right)$ were used. In the autoclaved PDA media, 0.05, 0.5, 5, 50 and 100 $\mu \mathrm{g} \mathrm{ml}^{-1}$ concentrations were used for each fungicide. In the control was added the same amounts of sterile pure water. Pathogen agar disc $(5 \mathrm{~mm})$ from a 3-day-old culture was inoculated at the centre of each PDA plate. Three discs were used for each concentration. All treatments were set up in three replications. Colony diameters were measured in a dark environment after four days of incubation at $25 \pm 1^{\circ} \mathrm{C}$ as reported by Delen et al. (1984).
Effective concentrations $\left(\mathrm{EC}_{50}\right)$ that inhibit mycelium growing at different concentrations of fungicides at the level of $50 \%$ were determined by using Probit analysis with the help of SPSS statistics program (Version 17.0, SPSS Inc., Chicago, IL, USA) using the values obtained in different concentrations for each chemical.

Determination of antifungal efficiencies of fungicides and non-volatile metabolites on grapes berries in controlled conditions: The antifungal efficiencies were also determined by grape tests in mature grapes in accordance with the method of Koplay et al. (2004). In berries tests, two isolates were selected considering the highest and lowest value of $\mathrm{EC}_{50}$ based on pathogens for each fungicide. Healthy grape berries were drilled once with the help of sterile injectors to avoid wound on grapes. The full (1/1) and half (1/2) doses recommended for each fungicide and $25 \%$ non-VM antagonists were sprayed separately on drilled grapes, and the berries were fixed on styrofoam molds with the help of adhesive tape. Control grapes were sprayed only with water. Styrofoam molds were then placed in plastic boxes, and sterile pure water was added to provide moisture. Berries were then inoculated with $B$. cinerea spore suspension at $1.0 \times 10^{6}$ spor $\mathrm{ml}^{-1}$ (Zahavi et al., 2000). The grapes held at $25 \pm 1^{\circ} \mathrm{C}$ in the climate room were evaluated after 7 days of storage. The research was established with four replications, and 5 of them were used in each replication. The diameter of lesions formed due to infection in grapes was measured to best illustrate the differences in the effectiveness of fungicides and their doses on pathogens in grapes.

Statistical analysis: Statistical analyses was done using SPSS software (Versiyon 17, SPSS Inc., Chicago, IL, USA) by applying Duncan Multi Comparison Test at $\mathrm{P}<0.01$ significance level, to determine difference among per treatment and lesion growing in control conditions.

\section{Results and Discussion}

In this study, T. harzianum and T. atroviride antagonists that developed under the same culture conditions limited the development of $B$. cinerea isolates. Table 1 shows the inhibition rates of isolates studied according to the dual culture technique and the average colony diameters. T. atroviridae EGE-K-71 antagonist was found to be effective on $B$. cinerea 338 MBAEM with an average colony diameter of $39.33 \mathrm{~mm}$ with $71.83 \%$ inhibition rate. T. harzianum EGE-K-38 antagonist was found to form a low zone with $47.62 \%$ inhibition rate developed against the isolates 362MBAEM, which was statistically significant from the others. The antagonistic activity of Trichoderma depends on multiple mechanisms that have a tendency to show a stronger or completely different effect than the obvious effect it has alone (Nallathambi et al., 2009; Howell, 2003). Various mechanisms include antibiosis, parasitism, inducing host-plant resistance, competition, and secretion of chitinolytic enzymes, mycoparasitism, and the production of inhibitory compounds (Harman et al., 2004). It has also been found that there is a wide 
Table 1: The average colony diameter and mycelial inhibition percentage of six Botrytis cinerea isolates by two Trichoderma strains EGE-K-38 and EGE$\mathrm{K}-71$ in dual culture test

\begin{tabular}{llll}
\hline Trichoderma species & $\begin{array}{l}\text { Botrytis İsolate } \\
\text { Numbers }\end{array}$ & $\begin{array}{l}\text { Average colony } \\
\text { diameter }(\mathrm{mm})^{\mathrm{a}}\end{array}$ & $\begin{array}{l}\text { Percentage of mycelial } \\
\text { inhibition (\%) }\end{array}$ \\
\hline & 228 MBAEM & $36.67 \pm 3.21^{\mathrm{abc}}$ & $56.00^{\mathrm{b}}$ \\
Trichoderma harzianum EGE-K-38 & 230MBAEM & $41.00 \pm 3.21^{\mathrm{ab}}$ & 51.38 \\
& 301 MBAEM & $26.67 \pm 4.17^{\mathrm{bc}}$ & 50.00 \\
& 302 MBAEM & $30.33 \pm 7.21^{\mathrm{abc}}$ & 63.89 \\
& 338 MBAEM & $42.00 \pm 1.15^{\mathrm{ab}}$ & 67.87 \\
Trihoderma atroviridae EGE-K-71 & 362 MBAEM & $44.00 \pm 3.60^{\mathrm{a}}$ & 47.62 \\
& 228MBAEM & $38.00 \pm 5.50^{\mathrm{abc}}$ & 54.40 \\
& 230MBAEM & $40.00 \pm 3.60^{\mathrm{abc}}$ & 52.57 \\
& 301 MBAEM & $31.33 \pm 5.48^{\mathrm{abc}}$ & 62.25 \\
& 302 MBAEM & $27.33 \pm 4.40^{\mathrm{bc}}$ & 67.46 \\
\hline
\end{tabular}

${ }^{a}$ Each value is an average of three replicates. Average were grouped by Duncan's Multiple Comparison Test $(P \leq 0.05)$, so the same letters how the same statistical group. ${ }^{b}$ The Inhibition rates for growth were calculated in the equation

range of volatile secondary metabolites produced by Trichoderma, such as ethylene, hydrogen cyanide, aldehydes, and ketones, which play an important role in the control of plant pathogens (Vey et al., 2001). Volatile and non-volatile compounds were associated with their ability to control pathogens (Harman, 2006). Dennis and Webster (1971) observed that Trichoderma spp. produced a volatile that inhibited the mycelium growth of $R$. solani and other test fungi. Volatile and non-volatile metabolites of Trichoderma spp. were also reported to reduce mycelial growth and sclerotium germination in sclerotiaforming fungi through various studies (Srinivasa et al., 2014; Kumar et al., 2017). Under the influence of two salts $\left(\mathrm{CaCl}_{2}\right.$ and $\mathrm{NaCl}$ ), the tolerance of $T$. harzianum and its antagonistic activity against $B$. cinerea were examined. In the absence of salt, the volatile and non-volatile secondary metabolites of $T$. harzianum showed inhibitions of $B$. cinerea by $52 \%, 79 \%$ and $81 \%$. Volatile metabolites produced by $T$. harzianum in the presence of a high concentration of calcium chloride (300 ppm) inhibited the mycelium growth of isolate B. cinerea no. B27 by $90.037 \%$ (Boualem et al., 2008). The effect of volatile and non-volatile metabolites of Trichoderma spp. against phytopathogens was determined previously by Rauti et al. (2014).

The volatile metabolites secreted by the $T$. atroviride strain were found to have the highest inhibition rates against Fusarium graminearum, Rhizoctonia solani and Pythium ultimum pathogens, with $45 \%, 40 \%$ and $37.5 \%$ inhibition rates, respectively. Chaudhary et al. (2020), a total of 31 Trichoderma spp. were studied for their antagonistic potentials against Rhizoctonia solani in dual culture, effect of volatile and nonvolatile metabolites on the growth inhibition of test pathogen under in-vitro condition. The most T. harzianum isolates showed higher growth inhibition of $R$. solani compared to the other isolates. Among the $T$. harzianum isolates, percent of growth inhibition was highest in SVPRT- THLi6 (90.9\%) isolate whereas the minimum growth inhibition rate $(41.9 \%)$ was observed in $T$. asperellum isolates SVPP-5. An isolate of T. reesei studied by ElNaggar et al. (2008) showed only a 30\% reduction in the growth of $B$. cinerea, $40.2 \%$ in the growth of $B$. fabae and only $4 \%$ in the growth of $B$. allii after five days of incubation. Fiume and Fiume (2006) observed the antagonistic activity of $T$. harzianum against gray mold from $4.7 \%$ after three days of incubation and up to $75.76 \%$ after seven days of incubation. Furthermore, $B$. cinerea and $T$. harzianum reported any state of no inhibition zone between colonies. In a study in Poland the antagonistic activities of 52 isolates of Trichoderma spp. against Botrytis cinerea were tested in vitro conditions using the dual culture technique. All of the tested Trichoderma isolates grew rapidly and covered the entire surface of the Petri dishes intensively after 10 days. The most effective T. atroviride (T43 and T52) strains revealed more than $70 \%$ of the growth inhibition of B. cinerea (Bogumił et al., 2013). In the present study, the $T$. atroviride strain had the highest inhibition rate $(71.83 \%)$ against the isolate 338MBAEM of $B$. cinerea phytopathogen and as per above similar results were obtained.

In the examination of antifungal effects of different fungicides and $25 \%$ non-VM concentration of Trichoderma spp., on prevention mycelial growth of $B$. cinerea, it was observed that 228MBAEM, 302MBAEM, and 362MBAEM isolates were highly sensitive than other fungicides except for EGE-K-71 Trichoderma isolate. Among the fungicides with different chemical structures included in the experiment, fenhexamide displayed the highest efficacy in the concentration range of $0.05-5.18 \mathrm{\mu g} \mathrm{ml}^{-1}$. Effective concentration values required for each fungicide in the experiments to reference were determined through Probit analysis. According to the results obtained, the drug which showed the highest fungicidal effect with the lowest $\mathrm{EC}_{50}$ value of 


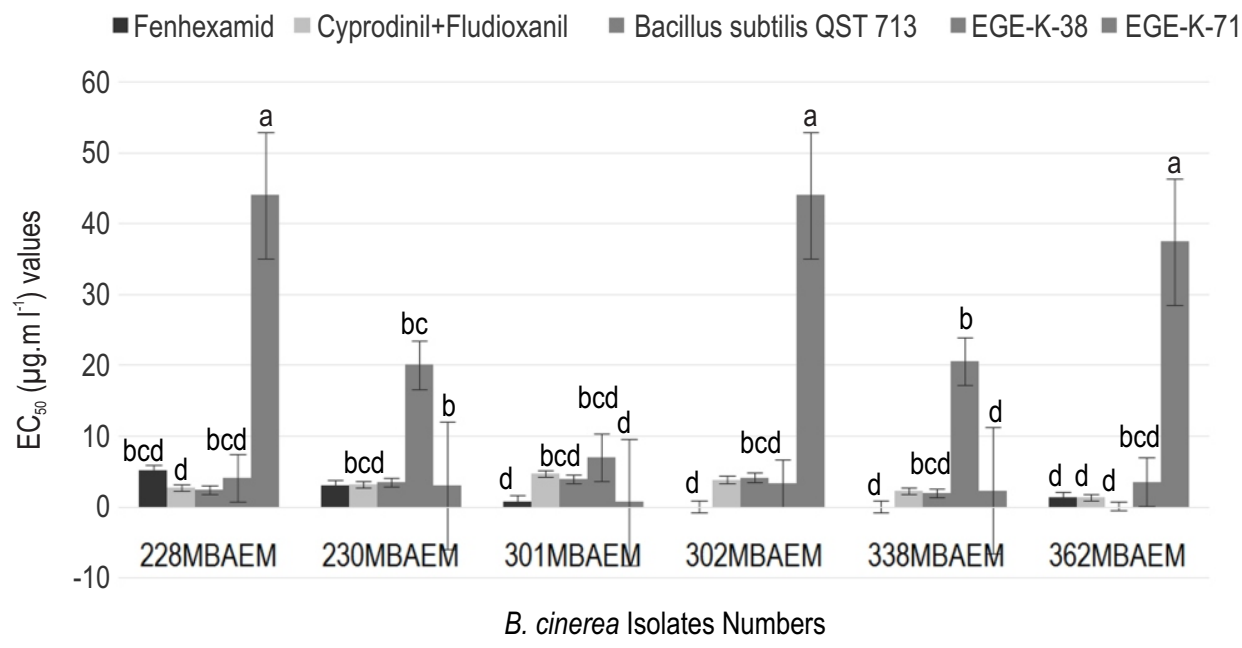

Fig.1: $\mathrm{EC}_{50}\left(\mu \mathrm{g} \mathrm{m}^{-1}\right)$ values of Fenhexamide, cyprodinil + fludioxanil, Bacillus subtilis QST 713 fungicides, and Trichoderma (EGE-K-38 and EGE-K-71) of $25 \%$ filtrate concentration against six B. cinerea isolate in in-vitro; * Different lower-case letters indicate significant differences according to Duncan Multiple Comparison Test $(\mathrm{P} \leq 0.05)$.

$0.05 \mu \mathrm{g} \mathrm{m}{ }^{-1}$ was determined to be fenhexamide, and this fungicide was followed by Bacillus subtilis QST 713 with $0.11 \mu \mathrm{g}$ $\mathrm{ml}^{-1}$, cyprodinil + fludioxonil with $1.39 \mathrm{\mu g} \mathrm{ml}^{-1}$, and Trichoderma harzianum EGE-K-38 active ingredient fungicides with $3.32 \mu \mathrm{g}$ $\mathrm{ml}^{-1}$ and metabolites. Among the applications, the lowest efficacy was shown against 228MBAEM and 302MBAEM isolates by Trichoderma atroviride EGE-K-71 that had the highest EC $_{50}$ value with $44.00 \mathrm{Mg} \mathrm{ml}^{-1}$, while a low EC50 value $\left(2.4 \mathrm{\mu g} \mathrm{ml}^{-1}\right)$ was obtained against 338MBAEM isolate (Fig. 1).

As a result, among the fungicides used in the study, fenhexamide $\left(0.05 \mathrm{ug} \mathrm{ml}^{-1}\right)$ against 338MBAEM and 302MBAEM isolates and against 301MBAE isolate, Trichoderma atroviride EGE-K-71 $\left(0.73 \mu \mathrm{g} \mathrm{ml}^{-1}\right)$ with low $\mathrm{EC}_{50}$ values were the most effective fungicide and metabolite. Fig. 1. Effective concentration $\left(E C_{50}\right)$ values which are necessary for $25 \%$ nonvolatile metabolites of Trichoderma spp. to prevent the mycelial growth of $B$. cinerea isolates by $50 \%$ was determined for the first time in this study. The bioactive compound trichodermin being a non-volatile metabolite was isolated from the endophytic fungus T. brevicompactum. It displayed significant inhibitory activity on $R$. solani and $B$. cinerea, with an $\mathrm{EC}_{50}$ of $0.25 \mathrm{\mu g} \mathrm{m}^{-1}$ and $2.02 \mu \mathrm{g}$ $\mathrm{ml}^{-1}$, respectively. However, a relatively poor inhibitory effect was shown against Colletotrichum lindemuthianum $\left(\mathrm{EC}_{50}=25.60 \mu \mathrm{g}\right.$ $\mathrm{ml}^{-1}$ ) (Shentu et al., 2014). In the study a total of 11 metabolites were obtained in the main secondary metabolites of two $T$. harzianum strains (T-4 and T-5). Of these metabolites, Harzianopyridone was the most effective and had an antifungal effect that inhibited the growth of $R$. solani, F. oxysporum and Sclerotium rolfsii by more than $90 \%\left(E_{50} 35.9-50.2 \mu \mathrm{g} \mathrm{ml}^{-1}\right.$ ) (Ahluwalia et al., 2015). Harzianopyridone is a powerful inhibitor of complex II (NADH-ubikinon reductase) enzymes in the mitochondrial respiratory chain in fungus (Lv et al., 2015). Four toxins (gliotoxin, dimethyl gliotoxin, viridin and viridiol) were isolated from T. virens. Of these toxins, Gliotoxin, Rhizoctonia Bataticola $\left(E_{50} 0.03 \mu \mathrm{g} \mathrm{ml}^{-1}\right)$, Macrophominia phaseolina $\left(E_{50}\right.$ $\left.1.76 \mu \mathrm{g} \mathrm{ml}^{-1}\right)$, Pythium deharyanum $\left(\mathrm{ED}_{50} 29.38 \mu \mathrm{g} \mathrm{ml}^{-1}\right)$ were effective by preventing mycelium development by $50 \%$ (Shyamli et al., 2005). The antagonistic effect of the metabolites of some isolates of Trichoderma genus in different concentrations (10\%, $20 \%, 25 \%, 50 \%$ ) on Botrytis cinerea, Rhizoctonia solani, Sclerotinia sclerotiorum, Sclerotium spp., Pythium ultimum, Phytophthora spp., Armillaria spp., Fusarium oxysporum, Alternaria solani and Gauemannomyces graminis pathogens was determined by the percentage inhibition of mycelial growth (Barakat et al., 2014; Brewer and Larkin, 2005; Woo et al., 2014). However, effective concentration values that inhibit the mycelial growth used to determine the fungicidal effect of metabolites by $50 \%$ was not investigated. In fact, fungal secondary metabolites that have a chemically low molecular weight $(<3 \mathrm{kDa})$ are used effectively in human treatment and the food industry. It is believed that this study will form a basis for the utilization of nonvolatile secondary metabolites as bio fungicides in agriculture.

Cyprodinil is included among the fungicides in anilopryminide group, and they have the risk of forming a moderate resistance. The maximum number of cyprodinil use with or without fludioxonil in a year was determined as two ( Leroux, 2004; Saito et al., 2014). EC Fo $_{5}$ value of cyprodinil in vitro against nine $B$. cinerea isolate obtained from vineyards in Chile was determined as $<0.001-4.89 \mathrm{Mg} \mathrm{ml}^{-1}$. It has been reported that new strategies should be developed in vineyards and should be applied in a combination with different groups in order to prevent resilience formation. 55 single-spore isolates of Botrytis cinerea were collected at the end of the season from vegetable crops grown in 18 greenhouses on the island of Crete, Greece by 
Table 2: The effect of full and half dose applications of fenhexamide, cyprodinil + fludioxanil, Bacillus subtilis QST 713, and Trihoderma (EGE-K-38 and EGE-K-71) on fruits under the controlled conditions of two Botrytis cinerea isolates selected according to $\mathrm{EC}_{50}$.

\begin{tabular}{|c|c|c|c|c|c|}
\hline Fungicide & Isolates & $\mathrm{EC}_{50}$ values $\left(\mu \mathrm{g} \mathrm{m} \mathrm{l}^{-1}\right)$ & Doses $\left(\mu g \mathrm{~m} \mathrm{l}^{-1} \text { e.m }\right)^{\mathrm{a}}$ & Lesion Diameter (mm) & Impact (\%) \\
\hline \multirow{7}{*}{ Fenhexamide } & \multirow{3}{*}{228} & \multirow{3}{*}{5.18} & 250 & $0.67 \pm b 0.06^{\mathrm{klc}}$ & 86.30 \\
\hline & & & 125 & $0.93 \pm 0.29^{k l}$ & 80.82 \\
\hline & & & 0 & $4.87 \pm 0.94^{\text {defgh }}$ & 0.00 \\
\hline & \multirow{4}{*}{338} & \multirow{4}{*}{0.05} & 250 & $0.47 \pm 0.24$ & 87.27 \\
\hline & & & 125 & $0.80 \pm 0.46^{k}$ & 78.18 \\
\hline & & & 0 & $3.67 \pm 1.07^{\text {efghij }}$ & 0.00 \\
\hline & & & 125 & $1.67 \pm 0.176^{\mathrm{jkl}}$ & 70.93 \\
\hline \multirow{4}{*}{ Cyprodinil+fludioxanil } & \multirow[t]{3}{*}{228} & \multirow[t]{3}{*}{2.80} & 62,5 & $2.67 \pm 0.98^{\text {ghijkl }}$ & 53.49 \\
\hline & & & 0 & $5.60 \pm 0.30^{\text {bcde }}$ & 0.00 \\
\hline & & & 125 & $0.73 \pm 0.54^{k l}$ & 85.71 \\
\hline & \multirow[t]{3}{*}{338} & \multirow[t]{3}{*}{2.04} & 62,5 & $1.53 \pm 0.64^{\mathrm{j} k \mathrm{k}}$ & 70.13 \\
\hline \multirow{8}{*}{ Bacillus subtilis QST 713} & & & 0 & $5.13 \pm 0.89^{\text {cdefg }}$ & 0.00 \\
\hline & & & 3750 & $2.60 \pm 0.80^{\text {hijkl }}$ & 73.47 \\
\hline & \multirow[t]{3}{*}{228} & \multirow[t]{3}{*}{3.54} & 1875 & $5.33 \pm 1.23^{\text {bcdef }}$ & 53.74 \\
\hline & & & 0 & $9.80 \pm 1.42^{\mathrm{a}}$ & 0.00 \\
\hline & & & 3750 & $1.27 \pm 0.29^{\mathrm{kl}}$ & 80.81 \\
\hline & \multirow[t]{3}{*}{338} & \multirow[t]{3}{*}{2.51} & 1875 & $3.07 \pm 0.70^{\text {fghijk }}$ & 53.54 \\
\hline & & & 0 & $6.60 \pm 1.00^{\text {bcd }}$ & 0.00 \\
\hline & & & 6250 & $2.20 \pm 0.30^{\mathrm{jkl}}$ & 71.79 \\
\hline \multirow{4}{*}{ Trihoderma harzianum EGE-K-38 } & \multirow[t]{3}{*}{228} & \multirow[t]{3}{*}{44.00} & 3125 & $3.93 \pm 2.07^{\text {efght }}$ & 49.57 \\
\hline & & & 0 & $7.80 \pm 0,34^{\mathrm{ab}}$ & 0.00 \\
\hline & & & 6250 & $1.40 \pm 0.50^{\mathrm{k} k \mathrm{k}}$ & 80.37 \\
\hline & \multirow[t]{3}{*}{338} & \multirow[t]{3}{*}{2.07} & 3125 & $2.40 \pm 0.70^{\text {nijkl }}$ & 66.36 \\
\hline \multirow{7}{*}{ Trihoderma atroviride EGE-K-71 } & & & 0 & $7.13 \pm 0.96^{\text {bcd }}$ & 0.00 \\
\hline & & & 6250 & $1.13 \pm 0.06^{k l}$ & 86.54 \\
\hline & \multirow[t]{3}{*}{228} & \multirow[t]{3}{*}{35.60} & 3125 & $2.45 \pm 0.61^{\text {hijkl }}$ & 66.83 \\
\hline & & & 0 & $7.33 \pm 1.39^{\text {abod }}$ & 0.00 \\
\hline & & & 6250 & $1.83 \pm 1.16^{\mathrm{jkl}}$ & 82.24 \\
\hline & \multirow[t]{2}{*}{338} & \multirow[t]{2}{*}{0.05} & 312,5 & $2.38 \pm 0.49^{\text {hijkl }}$ & 69.16 \\
\hline & & & 0 & $7.45 \pm 1.57^{\mathrm{abc}}$ & 0.00 \\
\hline
\end{tabular}

${ }^{a}$ Values represent mean of three replications of full and half doses of field recommended rate of fungicides and $25 \%$ non-VM of Trichoderma species used for two isolates of $B$. cinerea; ${ }^{b}$ Mean values followed by standard error of the mean; ${ }^{\circ}$ Averages were divided by Duncan test $(P \leq 0.05)$, so the same letters show statistically the same impacts

Myresiotis et al. (2007). They were tested for sensitivity to the anilinopyrimidine fungicides pyrimethanil and cyprodinil, the hydroxyanilide fungicide fenhexamid, the phenylpyrrole fungicide fludioxonil, the dicarboximide fungicide iprodione, and the benzimidazole fungicide carbendazim.

The $\mathrm{EC}_{50}$ values of the isolates ranged from 0.003 to 25.2 $\mu \mathrm{g} \mathrm{ml} l^{-1}$ and from 0.03 to $75.0 \mu \mathrm{g} \mathrm{ml}^{-1}$ for cyprodinil and pyrimethanil, respectively. In this study, the EC50 values of the isolates were obtained at the rate of 2.29-4.77 $\mathrm{\mu g} \mathrm{ml}^{-1}$ for cyprodinil + fludioxanil. It was determined that these $\mathrm{EC}_{50}$ values were realized between the values obtained for cyprodinil stated in the study by Myresiotis et al. (2007). The effectivenesses of nonvolatile metabolites and three fungicides, against $B$. cinerea isolates were shown with the grape test. Considering the results of the statistical analysis, it was determined that two doses of fenhexamide $\left(250 \mathrm{\mu g} \mathrm{ml}^{-1}, 125 \mathrm{~g} \mathrm{~m} \mathrm{ml}^{-1}\right)$ were effective on grape against isolates according to the highest and lowest $\mathrm{EC}_{50}$ values (Table 2). The full dose $\left(6250 \mu \mathrm{g} \mathrm{ml}^{-1}\right)$ of $T$. atroviride EGE-K-71 was effective against isolates 338MBAEM with 228MBAEM (Table 2). This antagonist is followed by cyprodinil + fludioxanil fungicide, B. subtilis QST 713 and T. harzianum EGE-K-38 antagonist, respectively. The full dose $\left(6250 \mu \mathrm{g} \mathrm{ml}^{-1}\right)$ of $T$. harzianum EGE-K-38 antagonist was determined to be effective at a rate of $71.79 \%$ against 228MBAEM isolates with a high $\mathrm{EC}_{50}$ value. $T$. atroviride EGE-K-71 was found to significantly inhibit lesion formation on grapes. Similar results were reported by Al-Saeedi and Al-Ani, (2014).

Inhibition effects of $25,50,75 \%$, and $100 \%$ non-volatile filtrate concentrations of $T$. harzianum $\mathrm{T} 1$ and $\mathrm{T} 2$ strains to prevent incubation periods of Alternaria spp. and Pythium spp. pathogens were evaluated. The $25 \%$ filtrate concentration of $T$. harzianum had a high percentage of inhibition of $63.53 \%$ and 
$67.78 \%$ at the $3^{\text {rd }}$ and $6^{\text {th }}$ day incubation period, respectively. Table 2. As a result of the test on grapes under controlled conditions, the isolates were found to be effective against fenhexamide, but the effectiveness $(70.93 \%$ at full dose, $53.49 \%$ at half dose) of cyprodinil + fludioxanil against 228MBAEM isolate with the high $\mathrm{EC}_{50}$ value was a little lower when compared to fenhexamide ( $86.30 \%$ at full dose, $80.82 \%$ at half dose). $B$. cinerea isolates are considered to hinder the development of $B$. cinerea isolates where $B$. subtilis QST 713 biological fungicide has good efficacy. The usage of Bacillus species, including Bacillus circulans, B. brevis and $B$. subtilis, as antagonists against $B$. cinerea was documented in laboratory and field conditions (Ben Maachia et al., 2015). B. subtilis strain QST 713, formulated as Serenade (Agra Quest, USA), and provided good gray mold control under field conditions in Chile. $\ln B$. subtilis, cyclic lipopeptides (surfactants, iturins, and fengicins) play a role in activating plant defenses; some of these cyclic lipopeptides may act directly against $B$. cinerea (Farace et al., 2015).

In our study, full dose $\left(3750 \mu \mathrm{g} \mathrm{m}^{-1}\right)$ administration of Serenade (B. subtilis strain QST 713) under controlled conditions had $73.47 \%$ and $80.81 \%$ effect on grapes in controlled $B$. cinerea isolates No. 228 and 338 , respectively. The $E_{50}$ value of 31 of the $638 \mathrm{~B}$. cinerea isolates derived from fenhexamide-administered vineyards is $\geq 0.1 \mathrm{\mu g} \mathrm{ml}^{-1}$, thus they are considered resistant. In the tests performed on grapes with 4 isolates of different endurance levels, $25 \%$ and $100 \%$ of the recommended dose of fenhexamide (150-600 $\left.\mu \mathrm{g} \mathrm{ml} \mathrm{m}^{-1}\right)$ were administered as a preservative and therapeutic. It was determined that isolates with $\mathrm{EC}_{50}$ values of 0.03 and $0.15 \mu \mathrm{g} \mathrm{ml}^{-1}$ could prevent disease with their recommended doses and that isolates with the $E_{50}$ value of 0.32 and $62.5 \mathrm{\mu g} \mathrm{ml}^{-1}$ could not. In ERG 27 gene of the isolates with an $\mathrm{EC}_{50}$ value of $62.5 \mathrm{\mu g} \mathrm{ml}^{-1}, \mathrm{~F} 427 \mathrm{~V}$ mutation was detected (Fournier et al., 2005). Because fenhexamide is a specialized fungicide in terms of the binding site, there is a risk of creating certain durability. In laboratory conditions, isolates improve endurance as they can find continuous, long and optimal growth conditions to metabolize fenhexamide, and because optimal conditions in nature do not occur exactly as desired, very few durable isolates may be found (Esterio et al., 2007; Suty and Stenzel, 1999).

In conclusion, this study showed that $T$. atroviride species is a new type of antagonistic fungus that can be used for controlling $B$. cinerea, the pathogen of bunch rot disease. The fungicidal effect of non-VM at the concentration of $25 \%$ of the T. harzianum and T. atroviride species was calculated for the first time using $\mathrm{EC}_{50}$ values in in vitro. It has been established that $25 \%$ of the non-VM and VM of the $T$. atroviride is as effective fungicides in inhibition the spore and mycelium production of $B$. cinerea as on grapes in post-harvesting. The study showed that secondary metabolites, which are alternative to fungicides as an environmentally friendly product, can be evaluated at pre and post-harvest against $B$. cinerea in the agents' bunch rots.

\section{Acknowledgment}

This study was carried out with the facilities of Manisa Viticulture Research Institute and we thank them for their support.

\section{Add-on Information}

Authors' contribution: N.G. Savas: Conceived of presented idea, developed the theory and performed computations, writing manuscript; M. Yıldız: Carried out experiment, R. Eltem: Provided consultancy; and E. Ozkale: Help in research and writing manuscript.

Research content: The research content of manuscript is original and has not published elsewhere.

Ethical approval: Not applicable

Conflict of interest: The authors declare that there is no conflict of interest.

Data from other sources: Not applicable

Consent to publish: All authors agree to publish the paper in Journal of Environmental biology.

\section{References}

Abano, E.E. and L.K Sam-Amoah: Application of antagonistic microorganisms for the control of postharvest decays in fruits and vegetables. Int. J. Adv. Biol. Res., 2, 1-8 (2012).

Ahluwalia, V., J. Kumar, V.S. Rana, O.P. Sati and S. Walia: Comparative evaluation of two Trichoderma harzianum strains for major secondary metabolite production and antifungal activity. Nat. Prod. Res., 29, 914-920 (2015).

Al-Saeedi, S.S. and B.M. Al-Ani: Study of antagonistic capability of Trichoderma harzianum isolates against some pathogenic soil borne fungi. Agric. Biol. J. N. Am., 5, 15-23 (2014).

Akgül, D.S., N.G. Savas, T. Teker, B. Keykubat, J.S. Mayorquın and A. Eskalen: Fungal trunk pathogens of Sultana seedless vineyards in Aegean region of Turkey. Phytopathol. Mediterra., 54, 380-393 (2015).

Amiri, A., S.M. Heath and N.A. Peres: Resistance to fluopyram, fluxapyroxad, and penthiopyrad in Botrytis cinerea from strawberry. Plant Dis., 98, 532-539 (2014).

Barakat, F.M., K.A. Abada, N.M. Abou-Zeid and Y.H.E El-Gammal: Effect of volatile and non-volatile compounds of Trichoderma spp. on Botrytis fabae the causative agent of faba bean chocolate spot. American J. Life Sci., 2, 11-18(2014).

Ben Maachia, S., R. Errakhi, M. Chérif, P. Nandal, T. Mohapatra and P. Bernard: Biological control of the grapevine diseases 'grey mold' and 'powdery mildew' by Bacillus B27 and B29 strains. Indian J. Exp. Biol., 53, 109-115(2015).

Brewer, M.T. and R.P. Larkin: Efficacy of several potential biocontrol organisms against Rhizoctonia solani on potato. Crop Protec., 24, 939-950 (2005).

Boualem, K., Y. Wach e, D. Garmyn, T. Karbowiak, A. Durand, P. Gervais and J.F. Cavin: Cloning and expression of genes involved in conidiation and surface properties of Penicillium camemberti grown in liquid and solid cultures. Res. Microbiol., 159, 110-117 
(2008).

Bogumił, A., L. Sas Paszt, A. Lisek, P. Trzciński and A. Harbuzov: Identification of new Trichoderma strains with antagonistic activity against Botrytis cinerea. Folia Horticul., 25, 123-132 (2013).

Brožová, J.: Mycoparasitic fungi Trichoderma spp. in plant protection Review. Plant Protect. Sci., 40, 63-74 (2004).

Chaudhary, S., S. Sagar, M. Lal, A. Tomar, V. Kumar and M. Kumar: Biocontrol and growth enhancement potential of Trichoderma spp. against Rhizoctonia solani causing sheath blight disease in rice. J. Environ. Biol., 41, 1034-1045 (2020).

Delen, N., M. Yıldız and H. Maraite: Benzimidazole and dithiocarbamate resistance of Botrytis cinerea on greenhouse crops in Turkey. Med. Fac. Landbauww. Rijksuniv. Gent., 49,153-16 (1984).

Dennis, C. and J. Webster: Antagonistic properties of species group of richoderma III. Hyphal interaction. Trnas. Briticsh Mycol. Soce., 57, 363-369 (1971).

Elad, Y., B. Williamson, P. Tudzynski and N. Delen: Botrytis spp. and disease they cause in agricultural systems-An introduction. In: Botrytis: Biology, Pathology and Control (Eds.: Y. Elad, B. Williamson, P. Tudzynski and N. Delen). Springer Netherlands Publishing Co. Inc, pp. 1-8 (2007).

El-Naggar, M., G.J. Kövics, E. Sándor and L. Irinyi: Mycoparasitism and antagonistic efficiency of Trichoderma reesei against Botrytis spp. Contrib. Bot., 43,141-147 (2008).

Elmer, P.A.G and T.J. Michailides: Epidemiology of Botrytis cinerea in orchard and vine crops. In: Botrytis: Biology, Pathology and Control (Eds.: Y. Elad, B. Williamson, P. Tudzynski and N. Delen). Springer Netherlands Publishing Co. Inc, pp. 243-272, (2007).

Esterio, M., J. Auger, C. Ramos and H. Garcia: First report of fenhexamid resistance isolates of Botrytis cinerea on grapevine in Chile. Plant. Dis., 91, 768 (2007).

Farace, G., O. Fernandez, L. Jacquens, F. Coutle, F. Krier, P. Jacques, C. Clemant, E.A. Barka, C. Jacquard and S. Dorey: Cyclic lipopeptides from Bacillus subtilis activate distinct patterns of defence responses in grapevines. Mol. Plant Pathol., 16, 177-187 (2015).

FAO: The website of food and agriculture organization of the United Nations, Retrieved in April, 19, 2019 from http://faostat.fao.org/ site/291/default.aspx. (2018).

Fiume, F. and G. Fiume: Biological control of Botrytis gray mould on tomato cultivated in greenhouse. Commun Agric. Appl. Biol. Sci., 71, 897-908 (2006).

Fournier, E., T. Giraud, C. Albertini and Y. Brygoo: Partition of the Botrytis cinerea complex in France using multiple gene genealogies. Mycologia, 97, 1251-1267 (2005).

Freeman, S., D. Minz, I. Kolesnik, O. Barbul, A. Zveibil and M. Mayman: Trichoderma biocontrol of Colletotrichum acutatum and Botrytis cinerea and survival in strawberry. Eur. J. Plant Path., 110, 361$370,(2004)$.

Gezgin, Y., D. Maral Gül, S. Sözer Şenşata, C.U. Kara, S. Sargın, F. Vardar Sukan and R. Eltem: Evaluation of Trichoderma atroviride and Trichoderma citrinoviride growth profiles and their potentials as biocontrol agent and biofertilizer. Turkish J. Bioche., 45, 1-13 (2019).

Hajieghrari, B.: Effect of some Iranian Trichoderma isolates on maize seed germination and seedling vigour. Afr. J. Biotechnol., 9, 4342$4347(2010)$.

Harman, G.E., C.R. Howell, A. Viterbo, I. Chet and M. Lorito: Trichoderma species-opportunistic, avirulent plant symbionts. Nature Rev. Microbiol., 2, 43-56 (2004).

Harman, G.E.: Overview of mechanism and uses of Trichoderma spp. Phytopathology, 96, 190-194 (2006).

Howell, C.R.: Mechanisms employed by Trichoderma species in the biological control of plant disease: the history and evolution of current concepts. Plant Dis., 87, 4-10 (2003).

Hoyos-Carvajal, L., S. Orduz and J. Bissett: Genetic and metabolic biodiversity of Trichoderma from Colombia and adjacent neotropic regions. Fungal Gene. Biol., 46, 615-631 (2009).

Jabnoun-Khiareddine, H., M. Daami-Remadi, F. Ayed and M. El Mahjoub: Biological control of tomato Verticillium wilt by using indigenous Trichoderma spp. Afr. J. Plant Sci. Biotech., 3, 26-36 (2009).

Joshi, B.B., R.P. Bhatt and D. Bahukhandi: Antagonistic and plant growth activity of Trichoderma isolates of Western Himalayas. J. Environ. Biol., 31, 921-928 (2010).

Karkachi, N.E., S. Gharbi, M. Kihal and J.E. Henni: Biological control of Fusarium oxysporum f.sp. lycopersici isolated from Algerian tomato by Pseudomonas fluorescens, Bacillus cereus, Serratia marcescens and Trichoderma harzianum. Res. J. Agron., 4, 31-34 (2010).

Kexiang, G., L. Xiaoguang, L. Yonghong, Z. Tianbo and W. Shuliang: Potential of Trichoderma harzianum and $T$. atroviride to control Botryosphaeria berengeriana f. sp. piricola, the cause of apple ring rot. J. Phytopathol., 150, 271-276 (2002).

Koplay, C., N. Delen and P. Kınay: Studies on the chemical control of Botrytis cinerea bunch rots on Sultanina table grapes. Paper presented at: XIII Botrytis Symposium, Antalya, Turkey, (2004).

Kumar, D. and S.C. Dubey: Management of collar rot of pea by the integration of biological and chemical methods. Indian Phytopathol., 54, 62-66 (2001).

Kumar, R., A. Sinha, S. Srivastava and G. Mahajan: Evaluation of biocontrol potential of some fungal decomposers of Sesbania aculeate L. green manure against some soil-borne plant pathogens. J. Environ. Biol., 38, 37-45 (2017).

Leroux, P., E. Fourntier, Y. Brygoo and M.L. Panon: Biodiversity and variability within Botrytis cinerea the causal agent of grey mold. Phytoma, 554, 38-42 (2002).

Leroux, P.: Chemical control of Botrytis and its resistance to chemical fungicides: In: Botrytis: Biology, Pathology and Control, (Eds.: Y. Elad, B. Williamson, P. Tudzynski and N. Delen) Dordrecht, The Netherlands: Kluwer Academic Publishers, pp. 195-222 (2004).

Lv, H.N., H. Chen, J. Qu, Y. Li, S.G. Ma and Y.B. Liu: Study on secondary metabolites of endophytic fungi Trichoderma harzianum. Mod. Chin. Med., 17, 427-430 (2015).

Mamgain, A., R. Roychowdhury and J. Tah: Alternaria pathogenicity and its strategic controls. Res. J. Biol., 1, 1-9 (2013).

Mamiev, M., N. Korolev and Y. Elad: Resistance to polyoxin AL and other fungicides in Botrytis cinerea collected from sweet basil crops in Israel. Eur. J. Plant Pathol., 137, 79-91 (2013).

Marques, E., I. Martins and S.C. Marques de Mello: Antifungal potential of crude extracts of Trichoderma spp. Biota Neotropica., 18, 20172028 (2018).

Mehrotra, R.S. and A. Aggarwal: Plant Pathology. Tata McGraw-Hill Publishing Company Limited, New Delhi, India (2003).

Mishra, B.K., R.K. Mishra, R.C. Mishra, A.K. Tiwari, R.S. Yadav and A Dikshit: Biocontrol efficacy of Trichoderma viride isolates against fungal plant pathogens causing disease in Vigna radiata L. Appl. Sci. Res., 3, 361-369, (2011).

Mokhtar, H. and D. Aid: Contribution in isolation and identification of some pathogenic fungi from wheat seeds, and evaluation of antagonistic capability of Trichoderma harzianum against those isolated fungi in-vitro. Agric. Biol. J. N. Am., 4, 145-154 (2013)

Morton, D.T. and N.H. Stroube: Antagonistic and stimulatory effect of microorganism upon Sclerotium rolfsii. Phytopathology, 45, 419-420 (1955).

Myresiotis, C. K., G. S. Karaoglanidis and K. Tzavella-Klonari: 
Resistance of Botrytis cinerea Isolates from vegetable crops to anilinopyrimidine, phenylpyrrole, hydroxyanilide, benzimidazole, and dicarboximide fungicides. Plant Dise., 91, 407-413 (2007).

Nallathambi, P., C. Umamaheswari, B.B.L. Thakore and T.A. More: Postharvest management of ber (Ziziphus mauritiana lamk) fruit rot fungicides and their combinations. Crop Prot., 28, 407-413 (2009).

Rauti, I., M. Badea-Doni, M. Calin, F. Oancea, G. Vasilescu, T. E. Sesan and L. Jecu: Effect of volatile and non-volatile metabolites from Trichoderma spp. against important phytopathogens. Rev. Chim. (Bucharest). 65, 1285-1288 (2014).

Saito, S., L. Cadle-Davidson and W. F. Wilcox: Analysis of fluopiccolide and propamocarb residues on tomato and soil using Qu ECh ERS sample perapration method in combination with GLC and GCMS. FoodAnal. Methods, 7, 1032-1042 (2014).

Shentu, X.P., X.H. Zhan, Z. Ma, X.P. Yu and C.X. Zhang: Antifungal activity of metabolites of the endophytic fungus Trichoderma brevicompactum from garlic. Braz. J. Microbiol., 45, 248-254 (2014).

Shyamli, S., D. Prem, T. Rs and S. Atar: Production and antifungal activity of secondary metabolites of Trichoderma virens. Pestic. Res. J., $17,26-29(2005)$.

Srinivasa, N., T.P. Devi, S. Sudhirkumar, D. Kamil, J.L. Borah and N. Prabhakaran: Bioefficacy of Trichoderma isolates against soilborne pathogens. Afr. J. Microbiol. Res., 8, 2710-2723 (2014).

Suty, A. and K. Stenzel: Iprovalicarb-sensitivity of Phytophthora infestans and Plasmopara viticola: Determination of baseline sensitivity and assessment of the risk of resistance. Pflanzenschutz Nachrich. Bayer., 52, 71-82 (1999).

Spiegel, Y. and I. Chet: Evaluation of Trichoderma spp. as a biocontrol agent against soliborne fungi and plant-parasitic nematodes in Israel. Integ. Pest Manag. Rev., 3, 169-175 (1998).

Verma, M., S.K. Brar, R.D. Tyagi, R.Y. Surumpalli and J.R Valéro: Antagonistic fungi, Trichoderma spp.: Panoply of biological control. Biochem. Eng. J., 37, 1-20, (2007).

Vey, A., R. Hoagland and T.M. Butt: Toxic metabolites of fungal biocontrol agents, In: Fungal Biocontrol Agents. Progress, Problems and Potential (Eds.: T.M. Butt, C. Jackson and N. Magan). CABI, Wallingford (2001).

Williamson, B., B. Tudzynski, P. Tudzynski, J.A.L. Van Kan: Botrytis cinerea: The cause of grey mould disease. Mol. Plant Pathol., 8, $561-580$ (2007).

Woo, S.L., M. Ruocco, F. Vinale, M. Nigro, R. Marra, N. Lombardi, A. Pascale, S. Lanzuise, G. Manganiello and M. Lorito: Trichodermabased products and their widespread use in agriculture. Open Mycol. J., 8, 71-126 (2014).

Yanar, Y., R. Cangi and K. Ozata: The determination of pesticide residue levels in brined vine leaves produced in Tokat Province, Selcuk Agr. Food Sci., 27, 267-275 (2015).

Zahavi, T., L. Cohen, B. Weiss, L. Schena, A. Daus, T. Kaplunov, J. Jutkhi, R. Ben-Arie and S. Droby: Biological control of Botrytis, Aspergillus and Rhizopus rots on table and wine grapes in Israel. Postharv. Biol. Technol., 20, 115-124 (2000). 